\title{
Hubungan Pengetahuan dan Perilaku Ibu tentang Gizi Seimbang dengan Status Gizi Anak TK di DesaYosowilangun Lor Kabupaten Lumajang
}

\author{
Rista Nur Fadila ${ }^{*}$, Dahlia Indah Amareta ${ }^{1}$, Ayu Febriyatna ${ }^{1}$ \\ ${ }^{I}$ Program Studi Gizi Klinik Jurusan Kesehatan \\ Politeknik Negeri Jember, Indonesia \\ Email : ristadila@yahoo.com
}

\begin{abstract}
Abstrack
Mother's nutritional knowledge determines all that the children eats. Mother's who have a good knowledge of nutrition will form a good balanced nutrition behavior for children. The behavior will affect the nutriet intake and nutritional status of children.The purpose of the study is to know the correlation mother's knowledge and attitudes on balanced nutrition with children's nutritional status in kindergartens Yosowilangun Lor village Lumajang Regency. This study employed Analytical Survey Research with Cross Sectional Design. The study was carried out on October 2016 in Muslimat NU 01 Yosowilangun Lor Kindergarten, Dharma Wanita 01 Yosowilangun Lor Kindergartenand Dharma Wanita 02 Yosowilangun Lor Kindergarten. The collecting data mothers's knowledge on balanced nutrition and mother's attitude on balance nutrition usedquestioner, and to collect child nutritional status data using Z- score with $B B / U$ indikator.This study involved 68 respondents. Based on bivariate analysis were tested statistically Somers'd test, the test of the correlationmother's knowledge and attitudes on balanced nutrition with children's nutritional status in kindergartens Yosowilangun Lor village Lumajang Regency obtained by value $p=0.000$ which shows the correlation of mother's knowledge on balanced nutrition with children's nutritional status in kindergartens Yosowilangun Lor village Lumajang Regency. On the test of attitudes on balanced nutrition with children's nutritional status in kindergartens Yosowilangun Lor village Lumajang Regency obtained by value $p=0.000$ shows that there is correlation attitudes on balanced nutrition with children's nutritional status in kindergartens Yosowilangun Lor village Lumajang Regency.
\end{abstract}

Keywods: Mother's Attitudes on Balanced Nutrition, Mother's Knowledgeon Balanced Nutrition, Nutritional Status

\section{Pendahuluan}

Anak merupakan individu yang berada dalam suatu rentang perubahan perkembangan yang dimulai dari bayi hingga remaja.Menurut usia, tahap perkembangan anak dibagi menjadi tahap perkembangan bayi (0-1 tahun), anak todler (1-3 tahun), anak usia pra sekolah (3-6 tahun), anak usia sekolah (6-12 tahun) serta remaja (12-21 tahun) 9Hidayat, 2008).

Status gizi merupakan faktor yang mempengaruhi kesehatan dan perkembangan anak. Status gizi yang baik dapat membantu proses perkembangan anak untuk mencapai optimal. Gizi yang cukup dapat memperbaiki ketahanan tubuh sehingga diharapkan tubuh akan bebas dari segala penyakit sedangkan gizi yang tidak terpenuhi akan menyebabkan masalah gizi pada anak (Setiyabudi, 2007).

Prevalensi status gizi kurus pada anak 5-12 tahun di Indonesia sebesar $11.2 \%$ terdiri dari $4.0 \%$ sangat kurus dan $7.2 \%$ kurus.
Prevalensi sangat kurus paling rendah di Bali (2.3\%) dan paling tinggi di Nusa Tenggara Timur (7.8\%). Secara nasional masalah gemuk pada anak umur 5-12 tahun masih tinggi yaitu $18.8 \%$, terdiri dari gemuk $10.8 \%$ dan sangat gemuk $8.8 \%$. Jawa timur merupakan salah satu provinsi yang memiliki prevalensi sangat gemuk di atas nasional. Menurut Kemenkes RI (2010) prevalensi status gizi lebih di Lumajang yaitu $0.95 \%$, gizi kurang $4.35 \%$ dan gizi buruk sebesar 0.81\%.Sedangkan menurut Dinkes Jatim (2012) di Desa Yosowilangun Kabupaten Lumajang prevalensi status gizi kurang $12 \%$ dan gizi lebih sebesar 2,8\%. Sedangkan data pada Dinkes Lumajang (2016), masalah gizi dapat disebabkan banyak faktor. Secara langsung dapat disebabkan karena penyakit dan rendahnya konsumsi pangan. Akses terhadap pangan dan praktik pemenuhan nutrisi oleh ibu yang kurang tepat mengakibatkan rendahnya konsumsi pangan 
dan timbulnya berbagai penyakit. Konsumsi pangan masyarakat masih belum sesuai dengan pesan umum gizi seimbang. Dari hasil penelitian Riskesdas 2010 menyatakan masih banyak penduduk yang tidak cukup mengkonsumsi sayur dan buah-buahan. Kualitas protein yang dikonsumsi rata-rata perorang perhari masih rendah karena sebagian besar berasal dari protein nabati. Konsumsi makanan dan minuman berkadar gula tinggi, garam tinggi dan lemak tinggi masih cukup tinggi (Kemnekes RI, 2014).

Ibu adalah penentu makanan yang dikonsumsi oleh anak. Kurangnya pengetahuan gizi dan kesehatan orang tua, khususnya ibu merupakan salah satu penyebab terjadinya kekurangan gizi pada anak. Seorang ibu yang sehari-harinya terbiasa menyiapkan makanan bagi anggota keluarga harus mempunyai pengetahuan dan keterampilan dasar tentang menu sehat serta bergizi seimbang. Frost (2010) menyebutkan gizi seimbang adalah makanan yang dikonsumsi sehari hari yang mengandung zat gizi dalam jenis dan jumlah yang sesuai dengan kebutuhan tubuh dengan memperhatikan prinsip keanekaragaman pangan, aktivitas fisik dan perilaku hidup bersih dan memantau berat badan secara teratur dalam rangka mempertahankan berat badan normal untuk mencegah masalah gizi (Kemenkes RI, 2014)

Desa Yosowilangun Lor adalah desa yang berada di Kabupaten Lumajang yang memiliki tiga Taman Kanak-Kanak (TK) yaitu Taman Kanak-Kanak (TK) Muslimat NU 01 Yosowilangun, Taman Kanak-Kanak (TK) Dharma Wanita 01 Yosowilangun Lor dan Taman Kanak-Kanak Dharma Wanita 02 Yosowilangun Lor. Hasil studi pendahuluan yang dilakukan di salah satu yang berada di Desa Yosowilangun Lor terdapat 27,78\% anak mempunyai status gizi kurang dan 5,56\% anak memiliki status gizi lebih.

Penelitian ini bertujuan untuk mengetahui hubungan pengetahuan dan perilaku ibu tentang gizi seimbang dengan status gizi anak TK di Desa Yosowilangun Lor Kabupaten Lumajang.

\section{Metode Penelitian}

\subsection{Metode Pengumpulan Data}

Penelitian ini dilakukan bulan Oktober 2016, metode yang digunakan adalah metode survei analitik dengan desain penelitian cross sectional.Populasi dalam penelitian ini adalah seluruh anak yang menjadi murid di Taman Kanak Kanak yang berada di Desa Yosowilangun Lor Kabupaten Lumajang yaitu TK Muslimat Nu 01 Yosowilangun Lumajang, TK Dharma Wanita 01 Yosowilangun Lor Lumajang dan TK DharmaWanita 02 Yosowilangun Lor Lumajang, sejumlah169 anak.Subjek dipilih menggunakan teknik simple random sampling. Besar subjek yang dibutuhkan pada penelitian ini adalah 68 murid tahun ajaran 2016-2017.

\subsection{Metode Analisis Data}

Analisis data yang digunakan yaitu analisis univariat untuk memperoleh gambaran mengenai karakteristik responden (umur, pekerjaan, jenis kelamin), pengetahuan dan perilaku ibu tentan gizi seimbang dengan menggunakan tabel distribusi frekuensi dan dianalisa secara deskriptif. Analisis bivariat dilakukan untuk mengetahui ada tidaknya hubungan antara variabel bebas (pengetahuan dan perilaku ibu tentang gizi seimbang) dan variabel terikat (status gizi). Jenisuji yang digunakanya itu uji Sommers'd. Seluruh teknik pengolahan data dianalisis secara komputerisasi dengan menggunakan SPSS 16.0 for Windowsyang telah memenuhi persetujuan etik Nomor: 551/PL17/LL/2017.

\section{Hasil dan Pembahasan}

Berikut ini merupakan tabel karakteristik ibu dan anak berdasarkan umur

Tabel 1. Karakteristik Ibu dan Anak Berdasarkan Umur

\begin{tabular}{lccc}
\hline \multicolumn{1}{c}{ Umur } & Min-Max & Mean & SD \\
\hline Umur & $20-45$ & 30,75 & 5,75 \\
Ibu (Th) & & & \\
Umur & $4-6$ & 5 & 0,69 \\
Anak & & & \\
Sumber: Data Primer (2016-2017) &
\end{tabular}

Berdasarkan tabel 1 diketahui distribusi umur ibu dan anak TK. Rata-rata usia ibu 30,75 $\pm 5,75$ tahun, dengan usia terendah 20 tahun dan usia tertinggi 45 tahun. Rata-rata usia anak $5 \pm 0,69$ tahun dengan usia terendah 
4 tahun dan usia tertinggi 6 tahun. Berikut ini merupakan tabel karakteristik tingkat pendidikan ibu.

Tabel 2. Karakteristik Tingkat Pendidikan Ibu

\begin{tabular}{lcc}
\hline Tingkat Pendidikan Ibu & Jumlah & $\begin{array}{c}\text { Persentase } \\
(\%)\end{array}$ \\
\hline Tamat SD & 17 & 25 \\
Tamat SMP & 25 & 36,7 \\
Tamat SMA & 19 & 27,9 \\
D1 & 2 & 2,9 \\
D3 & 1 & 1,4 \\
S1 & 4 & 5,8 \\
\hline Jumlah & 68 & 100 \\
\hline Sumber: Data Primer (2016-2017) &
\end{tabular}

Berdasarkan tabel 2 dapat diketahui bahwa dari 68 responden, sebagian besar pendidikan ibu yaitu tamat SMP sebanyak 25 orang $(36,7 \%)$ dan hanya sebagian kecil saja yang lulus pendidikan tinggi (D1, D3 dan S1) sejumlah 6 orang $(10,1 \%)$.

Berikut ini merupakan tabel karakteristik pekerjaan ibu sebagai berikut.

Tabel 3. Karakteristik Pekerjaan Ibu

\begin{tabular}{lcc}
\hline \multicolumn{1}{c}{ Pekerjaan } & Jumlah & $\begin{array}{c}\text { Persentase } \\
(\%)\end{array}$ \\
\hline Ibu Rumah Tangga & 64 & 94,1 \\
Guru & 1 & 1,47 \\
Petani & 3 & 4,4 \\
\hline Jumlah & 68 & 100 \\
\hline
\end{tabular}

Sumber: Data Primer (2016-2017)

Berdasarkan tabel 3 diketahui dari 68 responden, sebagian besarresponden yaitu sebanyak 64 orang sebagai ibu rumah tangga $(94,1 \%)$, dan hanya 1 orang responden $(1,47 \%)$ yang berprofesi sebagai guru.

Tabel 4. Karakteristik Anak Berdasarkan Jenis Kelamin

\begin{tabular}{ccc}
\hline Jenis Kelamin & Jumlah & $\begin{array}{c}\text { Persentase } \\
(\%)\end{array}$ \\
\hline Laki-Laki & 37 & $54,4 \%$ \\
Perempuan & 31 & $45,6 \%$ \\
\hline Jumlah & 68 & 100 \\
\hline
\end{tabular}

Sumber: Data Primer (2016-2017)

Berdasarkan penelitian yang telah dilakukan, jenis kelamin anak laki-laki sebanyak 37 anak $(54,4 \%)$ dan $31(45,6 \%)$ anak berjenis kelamin perempuan.

Tabel 5. Pengetahuan Ibu Tentang Gizi Seimbang

\begin{tabular}{ccc}
\hline Pengetahuan & Jumlah & Persentase (\%) \\
\hline Baik & 23 & 33,8 \\
Cukup & 18 & 26,5 \\
Kurang & 27 & 39,7 \\
\hline Jumlah & 68 & 100 \\
\hline
\end{tabular}

Sumber: Data Primer (2016-2017)
Berdasarkan tabel diatas menunjukkan bahwa sebagian besar responden $27(39,7 \%)$ berada pada kategori tingkat pengetahuan kurang. Tingkat pengetahuan cukup sebanyak 18 responden $(26,5 \%)$ dan tingkat pengetahuan baik sebanyak 23 responden $(39,7 \%)$.

Berikut ini merupakan tabel perilaku ibu tentang gizi seimbang:

Tabel 6. Perilaku Ibu Tentang Gizi Seimbang

\begin{tabular}{ccc}
\hline Perilaku & Jumlah & Persentase (\%) \\
\hline Baik & 25 & 36,8 \\
Cukup & 14 & 20,6 \\
Kurang & 29 & 42,6 \\
\hline Jumlah & 68 & 100 \\
\hline
\end{tabular}

Sumber: Data Primer (2016-2017)

Tabel diatas menunjukkan bahwa sebagian besar responden $29(42,6 \%)$ berada pada kategori tingkat perilaku kurang. Sedangkan yang paling sedikit yaitu 14 responden memiliki tingkat perilaku cukup.

Tabel berikut menggambarkan tentang status gizi anak

Tabel 7. Status Gizi Anak

\begin{tabular}{ccc}
\hline Status Gizi & Jumlah & Persentase (\%) \\
\hline Baik & 29 & 42,6 \\
Kurang & 38 & 55,9 \\
Lebih & 1 & 1,5 \\
\hline Jumlah & 68 & 100 \\
\hline
\end{tabular}

Sumber: Data Primer (2016-2017)

Tabel diatas menunjukkan bahwa sebagian besar anak $38(55,9 \%)$ memiliki status gizi kurang, dan hanya $1(1,5 \%)$ orang anak yang memiliki status gizi lebih.

Sedangkan tabel berikut merupakan tabel yang menggambarkan Hubungan pengetahuan Ibu Tentang Gizi Seimbang Dengan Status Gizi Anak TK di Desa Yosowilangun Lor Kabupaten Lumajang

Tabel 8. Hubungan pengetahuan Ibu Tentang Gizi Seimbang Dengan Status Gizi Anak TK di Desa Yosowilangun Lor Kabupaten Lumajang

\begin{tabular}{|c|c|c|c|c|c|c|}
\hline \multirow[b]{2}{*}{$\begin{array}{l}\text { Pengetah } \\
\text { uan Ibu } \\
\text { tentang } \\
\text { Gizi } \\
\text { Seimbang }\end{array}$} & \multicolumn{3}{|c|}{ Status Gizi Anak } & \multirow{2}{*}{$\begin{array}{l}\text { Total } \\
\mathrm{n}(\%)\end{array}$} & \multirow[t]{2}{*}{$\mathrm{P}$} & \multirow[t]{2}{*}{$r$} \\
\hline & $\begin{array}{l}\text { Baik } \\
\text { n (\%) }\end{array}$ & $\begin{array}{c}\text { Kurang } \\
\mathrm{n}(\%)\end{array}$ & $\begin{array}{l}\text { Lebih } \\
\text { n (\%) }\end{array}$ & & & \\
\hline Baik & $16(23,5)$ & $6(8,8)$ & $1(1,4)$ & $\begin{array}{c}23 \\
(33,8)\end{array}$ & & \\
\hline Cukup & $8(11,7)$ & $10(14,7)$ & $0(0)$ & $\begin{array}{c}18 \\
(26,4)\end{array}$ & $\begin{array}{c}0,00 \\
0\end{array}$ & $\begin{array}{l}0,3 \\
39\end{array}$ \\
\hline Kurang & $5(7,3)$ & $22(32,3)$ & $0(0)$ & $\begin{array}{c}27 \\
(39,7)\end{array}$ & & \\
\hline
\end{tabular}




\begin{tabular}{lllll}
\hline $\begin{array}{l}\text { Total n } \\
\text { (\%) }\end{array}$ & $29(42,5)$ & $38(55,9)$ & $1(1,4)$ & $\begin{array}{l}68 \\
(100)\end{array}$ \\
Sumber: Data Primer (2016-2017) & &
\end{tabular}

Berdasarkan uji Somers'd yang dilakukandinyatakan bahwa ada hubungan pengetahuan ibu tentang gizi seimbang dengan status gizi anak, serta diperoleh correlation coefficient sebesar 0,339 yang berarti memiliki hubungan lemah. Sedangkan arah korelasi searah (positif) yang berarti semakin kurangpengetahuanibu tentang gizi seimbang maka semakinkurangstatus gizi anak. Hasil penelitian ini sesuai dengan penelitian yang dilakukan oleh Rika tentang pengetahuan ibu tentang gizi dan status gizi anak usia 1-3 tahun yang dilakukan pada responden di wilayah kerja Puskesmas Rejosari yang menyatakan bahwa ada hubungan yang bermakna antara pengetahuan ibu tentang gizi dengan status gizi anak 1-3 tahun yang menunjukkan hasil dari 98 responden pengetahuan yang dimiliki ibu sebagian besar rendah yaitu sebanyak 62 responden $(63,3 \%)$ dengan status gizi anak terbanyak yaitu status gizi kurang sebanyak 52 responden (53,06\%) (Rika,dkk., 2013).

Hasil penelitian yang dilakukan di Desa Yosowilangun Lor Kabupaten Lumajang menunjukkan bahwa sebagian besar ibu mempunyai pengetahuan kurang tentang gizi seimbang. Dari 20 pertanyaan yang diajukan sebagian besar responden menjawab salah pada point penyusunan menu yang beragam, fungsi vitamin, karbohidrat, dan protein, serta jenis dan kandungan zat gizi yang ada dalam makanan. Hal ini dikarenakan sebagian besar pendidikan ibu adalah SMP sehingga minim pengetahuan.

$$
\text { Pengetahuan yang berhubungan }
$$
dengan masalah kesehatan akan mempengaruhi gangguan kesehatan pada kelompok tertentu. Kurangnya pengetahuan tentang gizi akan mengakibatkan berkurangnya kemampuan untuk menerapkan informasi dalam kehidupan sehari-hari yang merupakan salah satu penyebab terjadinya masalah gizi. Dalam Notoatmodjo, 2007, sebagian besar responden yaitu ibu rumah tangga sehingga kesulitan untuk mendapatkan informasi mengenai gizi seimbang dan menu seimbang yang baik untuk anak, karena minimnya sumber informasi untuk mereka yang hanya diam di rumah sebagai ibu rumah tangga.
Berdasarkan penelitian yang dilakukan, ibu yang menunggu anak disekolah mengijinkan anak membeli sosis di sekolah. Sosis, mie dan makanan ringan (chiki) mengandung banyak pengawet, pewarna dan MSG. Bagi anak yang sensitif pengawet dan pewarna dapat menyebabkan gejala alergi baik pada tubuh dan otaknya, disamping itu juga menimbulkan masalah diare. Alergi pada zatzat aditif atau zat-zat tertentu pada makanan dapat mempengaruhi suasana hati, perilaku, dan proses berfikir. Bahkan dalam jangka panjang akan mempertinggi risiko kanker. Ibu mengijinkan anak membeli sosis disekolah karena dengan membeli sosis ibu menganggap hal tersebut dapat mengganti makanan yg seharusnya dikonsumsi pada saat sarapan karena anak jarang mau untuk sarapan di rumah. Hal ini terjadi karena minimnya pendidikan ibu dan kurangnya pengetahuan ibu tentang kandungan dan zat-zat yang berbahaya yang terdapat di dalam sosis. Sebagian besar ibu hanya tamat Sekolah Menengah Pertama (SMP). Pendidikan adalah suatu proses belajar yang berarti dalam pendidikan itu terjadi proses pertumbuhan, perkembangan atau perubahan ke arah yang lebih dewasa, lebih baik dan lebih matang pada diri individu, kelompok atau masyarakat. Semakin tinggi tingkat pendidikan seseorang semakin mudah pula mereka menerima informasi, sebaliknya semakin rendah tingkat pengetahuan seseorang semakin sulit pula mereka menerima informasi. ${ }^{11}$ Sebagian besar responden adalah ibu rumah tangga sehingga kesulitan untuk mendapatkan informasi mengenai kesehatan dan gizi karena kegiatan mereka sehari hari hanya dilakukan dirumah sebagai ibu rumah tangga.

Berdasarkan peneltian yang dilakukan kebanyakan responden tidak mengetahui pentingnya buah dan sayuran untuk anak. Responden tidak membiasakan anak mengkonsumsi buah dan sayuran sejak kecil sehingga ketika anak memasuki usia pra sekolah anak tidak mau mengkonsumsi sayur dan buah yang ibu mereka berikan. Hal ini dikarenakan kurangnya pengetahuan ibu tentang manfaat sayuran dan buah untuk kesehataan anak, sehingga berdampak pada pola pemberian dan jenis makanan pada anak dan juga masalah gangguan pencernaan pada anak yang responden keluhkan, seperti susah 
buang air besar. Secara umum sayuran dan buah-buahan merupakan sumber berbagai vitamin, mineral dan serat pangan. Sebagai vitamin, mineral yang terkandung dalam sayuran dan buah-buahan berperan sebagai antioksidan atau penangkal senyawa jahat dalam tubuh. Kurangnya konsumsi buah dan sayur yang mengandung serat dapat mengakibatkan sembelit yang terjadi pada anak. Menurut Sulistyoningsih (2011), kebiasaan ini masih belum sesuai dengan pesan khusus gizi seimbang untuk anak usia 2-6 tahun yaitu memperbanyak konsumsi buah dan sayuran untuk anak. Berikut merupakan tabel hubungan perilaku ibu tentang gizi seimbang dengan status gizi anak TK di desa Yosowilangun Lor Kabupaten Lumajang

Tabel 9. Hubungan Perilaku Ibu Tentang Gizi Seimbang Dengan Status Gizi Anak TK di Desa Yosowilangun Lor Kabupaten Lumajang

\begin{tabular}{|c|c|c|c|c|c|c|}
\hline \multirow[b]{2}{*}{$\begin{array}{l}\text { Perilaku } \\
\text { Ibu } \\
\text { Tentang } \\
\text { Gizi } \\
\text { Seimbang }\end{array}$} & \multicolumn{3}{|c|}{ Status Gizi Anak } & \multirow{2}{*}{$\begin{array}{l}\text { Total } \\
\text { n (\%) }\end{array}$} & \multirow[t]{2}{*}{$\mathrm{P}$} & \multirow[t]{2}{*}{$\mathrm{r}$} \\
\hline & $\begin{array}{c}\text { Baik } \\
\text { n (\%) }\end{array}$ & $\begin{array}{c}\text { Kurang } \\
\mathrm{n}(\%)\end{array}$ & $\begin{array}{l}\text { Lebih } \\
\text { n (\%) }\end{array}$ & & & \\
\hline Baik & $17(25)$ & $7(10,2)$ & $1(1,4)$ & $\begin{array}{c}25 \\
(36,7)\end{array}$ & & \\
\hline Cukup & $8(11,7)$ & $6(8,8)$ & $0(0)$ & $\begin{array}{c}14 \\
(20,5)\end{array}$ & $\begin{array}{l}0,0 \\
00\end{array}$ & $\begin{array}{l}0,3 \\
89\end{array}$ \\
\hline Kurang & $4(5,58)$ & $25(36,7)$ & $0(0)$ & $\begin{array}{c}29 \\
(42,6)\end{array}$ & & \\
\hline $\begin{array}{l}\text { Total } \mathrm{n} \\
\text { (\%) }\end{array}$ & $29(42,5)$ & $38(55,9)$ & $1(1,4)$ & $\begin{array}{c}68 \\
(100)\end{array}$ & & \\
\hline
\end{tabular}

Berdasarkan uji Somers'd yang dilakukan dinyatakan bahwa ada hubungan perilaku ibu tentang gizi seimbang dengan status gizi anak, serta diperoleh correlation coefficient sebesar 0,389 yang berarti memiliki hubungan lemah. Sedangkan arah korelasi searah (positif) yang berarti semakin kurang perilaku ibu tentang gizi seimbang maka semakin kurang status gizi anak. Hasil penelitian ini sesuai dengan penelitian yang dilakukan oleh Mardiana tentang hubungan perilaku gizi ibu dan status gizi balita di Puskesmas Tanjung Beringin Kecamatan Hinai Kabupaten Langkat yang dilakukan pada 87 orang responden di wilayah kerja Puskesmas Tanjung Beringin Kecamatan Hinai Kabupaten Langkat, menyatakan bahwa ada hubungan bermakna antara perilaku ibu dengan status gizi balita hasil penelitian diketahui bahwa status gizi balita baik $(72,4 \%)$, status gizi balita kurang $(25,2 \%)$, status gizi balita buruk $(1,2 \%)$ dan status gizi balita lebih $(1,2 \%)$ (andriani, dkk., 2013).
Hasil penelitian yang dilakukan di Desa Yosowilangun Lor Kabupaten Lumajang menunjukkan bahwa sebagian besar ibu mempunyai perilaku kurang tentang gizi seimbang. Dari 15 pernyataan yang diajukan ada beberapa point perilaku gizi seimbang yang jarang dilakukan oleh responden yaitu : menjaga dan memperhatikan berat badan anak, membiasakan sarapan, memberikan makanan yang mengandung protein hewani seperti ikan serta membiasakan minum susu setiap hari, dari jawaban responden dapat diketahui bahwa responden belum mampu menerapkan pesan gizi seimbang dengan baik, sesuai dengan PUGS 2014. Perilaku ibu tentang gizi seimbang merupakan hal yang berkaitan dengan tindakan atau kegiatan ibu yang sesuai dengan pesan umum gizi seimbang. Frozt, et.al. (2010) menyebutkan perilaku dibentuk melalui suatu proses dan berlangsung dalam interaksi manusia dengan lingkungannya. Faktor-faktor yang mempengaruhi terbentuknya perilaku dibedakan menjadi dua, yaitu faktor intern dan faktor ekstern. Faktor intern mencakup pengetahuan, kecerdasan, persepsi, emosi motivasi yang berfungsi mengolah rangsang dari luar sedangkan faktor ekstern meliputi lingkungan sekitar, baik fisik maupun non fisik sperti iklim, manusia, sosial, ekonomi, kebudayaan dan sebagainya.

Salah satu faktor yang mempengaruhi status gizi anak adalah perilaku ibu dalam memilih dan memberikan makanan, karena perilaku ibu mempengaruhi bagaimana masyarakat mampu memenuhi persediaan pangan individu dan keluarganya. Masih banyak penduduk yang tidak cukup mengkonsumsi sayuran dan buah-buahan. Kualitas protein yang dikonsumsi rata-rata perorang perhari masih rendah karena sebagian besar berasal dari protein nabati. ${ }^{7}$ Perilaku ibu yang masih rendah dapat disebabkan karena kurangnya tingkat pengetahuan ibu tentang gizi seimbang dan kurangnya kemampuan dalam menerapkan di kehidupan sehari - hari (Frost,et.al., 2010).

Berdasarkan penelitian yang
dilakukan, banyak responden yang menyediakan mie di rumah sebagai makanan selingan untuk anak karena anak suka dan selalu meminta dibuatkan mie instan ketika lapar, apabila dilakukan secara terus menerus akan menimbulkan akibat yang kurang baik 
pada anak karena mie instan mengandung msg dan pengawet yang kurang baik untuk kesehatan anak dan hal tersebut tidak sesuai dengan pesan umum gizi seimbang untuk membatasi konsumsi pangan manis, asin dan berlemak. Kebiasaan atau pantangan makanan yang merugikan, kesukaan yang berlebihan terhadap jenis makanan tertentu serta sosial ekonomi orangtua juga dapat mempengaruhi status gizi anak (Hidayat,dkk., 2008).

Berdasarkan wawancara kuesioner perilaku ibu tentang gizi seimbang yang dilakukan peneliti, responden jarang memberikan daging ataupun ikan kepada anak dikarenakan kondisi ekonomi yang kurang sehingga sang anak terbiasa mengkonsumsi lauk nabati seperti tahu dan tempe sejak kecil sehingga ketika sesekali ibu memberi ikan sang anak menolak karena tidak terbiasa. Dari kejadian di atas dapat dilihat bahwa responden belum dapat memenuhi pesan umum gizi seimbang pada point membiasakan konsumsi lauk pauk yang mengandung protein tinggi, hal ini menyebabkan kurangnya asupan protein hewani pada anak yang dapat mempengaruhi kesehatan dan status gizi anak. Dalam memenuhi kebutuhan gizi seimbang faktor ekonomi menjadi salah satu faktor yang menentukan seseorang dapat memenuhi kebutuhan gizi seimbang yang sesuai dengan yang dibutuhkan ataupun yang tidak sesuai dengan kebutuhannya. Status ekonomi orang tua dapat mempengaruhi perubahan status gizi anak. Penyediaan makanan bergizi membutuhkan dana yang tidak sedikit, sehingga perubahan status gizi dipengaruhi oleh status ekonomi. Seseorang dengan status ekonomi yang kurang biasanya kesulitan dalam penyedian makanan bergizi, sebaliknya orang dengan status ekonomi tinggi lebih mudah untuk menyediakan makanan bergizi. ${ }^{15}$

Hasil wawancara yang dilakukan dengan salah satu responden, anak terlalu suka berlebihan terhadap bubur bayi instan karena setiap hari anak selalu minta dibuatkan bubur bayi instant ketika selesai makan pagi, siang dan malam. Hal ini terjadi karena ketika usia 1 tahun ibu selalu membuatkan bubur bayi instan dan berlanjut sampai anak memasuki usia pra sekolah. Perilaku ibu dalam pemberian makan anak sudah baik karena dengan memberikan bubur bayi instant kepada anak dapat menambahkan asupan karbohidrat yang belum tercukupi karena anak hanya mau mengkonsumsi 2-3 sendok nasi saja. Sedangkan status gizi anak lebih, hal ini dikarenakan faktor genetik yang didapatkan dari kedua orang tuanya yang memiliki status gizi lebih. Rata-rata faktor genetik memberikan pengaruh sebesar 33\% terhadap berat badan seseorang (Frost,et.al., 2010).

Berdasarkan penelitian yang dilakukan beberapa anak jarang mau untuk sarapan. Karena terbiasa bangun kesiangan dan tidak mau sarapan. Sehingga pada saat disekolah anak - anak membeli cilok bakar yang dijual oleh penjual yang berdagang di depan sekolah dan para ibu membiarkan anaknya membelinya karena ketika dirumah tidak mau sarapan. Kebiasaan ini tidak baik apabila dilakukan secara terus menerus karena sarapan setiap hari penting terutama bagi anak-anak karena mereka sedang tumbuh dan mengalami perkembangan otak yang sangat tergantung pada asupan makanan secara teratur. Dalam upaya memenuhi kebutuhan zat gizi selama sehari dianjurkan agar anak makan secara teratur 3 kali sehari dimulai dengan sarapan, atau makan pagi, makan siang, dan makan malam (Frost, et.al. (2010)

\section{Kesimpulan dan Saran}

\subsection{Kesimpulan}

1. Ada hubungan pengetahuan ibu tentang gizi seimbang dengan status gizi anak TK di Desa Yosowilangun Lor Kabupaten Lumajang.

2. Ada hubungan perilaku ibu tentang gizi seimbang dengan status gizi anak TK di Desa Yosowilangun Lor Kabupaten Lumajang.

\subsection{Saran}

1. Bagi peneliti selanjutnya diharapkan dapat mencantumkan variabel-variabel lain yang dapat mempengaruhi status gizi anak (Pendapatan, Pola makan dan Kebudayaan).

2. Bagi masyarakat khususnya ibu diharapkan untuk membawakan bekal kepada anak agar asupan makanan anak tetap terpenuhi selama di sekolah sehingga dapat mencapai status gizi yang normal. 
3. Bagi instansi pendidikan diharapkan dapat memberika penyuluhan, sosialisasi dan promosi kesehatan ke sekolah sekolah terdekat mengenai gizi seimbang dan jenis makanan bergizi yang dapat meningkatkan status gizi khususnya anak.

4. Bagi Taman Kanak - Kanak yang berada di Desa Yosowilangun Lor Kabupaten Lumajang sebaiknya disediakan alat untuk menimbang berat badan dan mengukur tinggi badan anak sehingga dapat dilakukan kegiatan pemantauan berat badan dan tumbuh kembang anak.

\section{Daftar Pustaka}

Hidayat, A. Aziz Alimul. 2008. Pengantar

Ilmu Kesehatan Anak untuk

Pendidikan Kebidanan. Jakarta:

Salemba Medika.

Setiyabudi.R. 2007. Pengantar Gizi Masyarakat. Jurnal Gizi. [ $10 \mathrm{Mei}$ 2016]. http://lib.ui.ac.id//201509/S52584

Kementrian kesehatan RI. 2010. Laporan Hasil Riset Kesehatan Dasar. Badan Penelitian dan Pengembangan Kesehatan Departemen Kesehatan RI.

Dinas Kesehatan Jawa Timur. 2012. Profil Kesehatan Jawa Timur.

Dinas Kesehatan Lumajang. 2016. Profil Kesehatan Lumajang.

Kementrian kesehatan RI. 2010. Laporan Hasil Riset Kesehatan Dasar. Badan Penelitian dan Pengembangan Kesehatan Departemen Kesehatan RI.

Kementrian kesehatan RI. 2014. Pedoman Gizi Seimbang. Badan Penelitian dan Pengembangan Kesehatan Departemen Kesehatan RI.

Frost, Michelle Bellessa. 2010 Maternal education and child nutritional status in Bolivia. Social Science \& Medicine.
Rika., Ganis, dan Wasisto. 2013. Hubungan Pengetahuan Ibu Tentang Gizi Dengan Status Gizi Anak usia 1-3 tahun. Jurnal Ilmu Kesehatan. [21 Mei 2016]. http// Jurnal Stikes.ac.ID.PHP/571.K.

Notoatmodjo, Soekidjo. 2007. Ilmu Kesehatan Masyarakat. Jakarta: Rineka Cipta.

Notoatmodjo, Soekidjo. 2007. Kesehatan Masyarakat Ilmu Dan Seni. Jakarta: Rineka Cipta.

Arisman. 2009. Gizi Dalam Daur Kehidupan. Jakarta: Buku Kedokteran EGC.

Sulistyoningsih, Hariyani. 2011. Gizi untuk Kesehatan Ibu dan Anak. Yogyakarta: Graha Ilmu.

Marimbi, Hanum. 2010. Tumbuh Kembang, Status Gizi Dan Imunisasi Dasar Pada Balita. Yogyakarta: Nuha Medika

Hidayat, A. Aziz Alimul. 2008. Pengantar Ilmu Kesehatan Anak untuk Pendidikan Kebidanan. Jakarta: Salemba Medika.

Andriani, Merryana., Wijatmadi, Bambang. 2013. Pengantar Gizi Masyarakat.

Mulyaningsih,Fitri.2008. Hubungan Antara Pengetahuan Ibu Tentang Gizi Balita Dan Pola Makan Balita Terhadap Status Gizi Balita Di Kelurahan Srihandono Kecamatan Pundong. Skripsi. Universitas Negeri Yogyakarta 